\title{
Microbiological Composition of Diets of Cactus Pear-Based with Increasing Levels of Buffel Grass Hay and Relationship to Nutritional Disorders in Sheep
}

\author{
Diego de S. Vieira ${ }^{1}$, Juliana S. de Oliveira ${ }^{1}$, Edson M. Santos ${ }^{1}$, Betina Raquel C. dos Santos ${ }^{1}$ (D), \\ Luís Fernando B. Pinto ${ }^{2} \mathbb{D}$, Anderson de M. Zanine ${ }^{3} \mathbb{D}$, Diego Francisco O. Coelho ${ }^{1}$, Gilberto de C. Sobral ${ }^{1}$, \\ Guilherme M. Leite ${ }^{1}$, Rafael L. Soares ${ }^{1}$, Francisco Naysson de S. Santos ${ }^{3, *}$, Maria Alyne C. Santos ${ }^{1}$, \\ Nelquides B. Viana ${ }^{1}$, Paulo da C. Torres Júnior ${ }^{1}$ and Paloma G. B. Gomes ${ }^{1}$
}

Citation: Vieira, D.d.S.; Oliveira, J.S.d.; Santos, E.M.; Santos, B.R.C.d.; Pinto, L.F.B.; Zanine, A.d.M.; Coelho, D.F.O.; Sobral, G.d.C.; Leite, G.M.; Soares, R.L.; et al. Microbiological Composition of Diets of Cactus Pear-Based with Increasing Levels of Buffel Grass Hay and Relationship to Nutritional Disorders in Sheep. Animals 2022, 12, 500. https:// doi.org/10.3390/ani12040500

Academic Editor: Manuel Fondevila

Received: 1 January 2022

Accepted: 15 February 2022

Published: 17 February 2022

Publisher's Note: MDPI stays neutral with regard to jurisdictional claims in published maps and institutional affiliations.

Copyright: (C) 2022 by the authors. Licensee MDPI, Basel, Switzerland. This article is an open access article distributed under the terms and conditions of the Creative Commons Attribution (CC BY) license (https:// creativecommons.org/licenses/by/ $4.0 /)$.
1 Department of Animal Science, Federal University of Paraiba, Areia 58397-000, Paraiba, Brazil; diegoosousa@live.com (D.d.S.V.); juliana@cca.ufpb.br (J.S.d.O.); edson@cca.ufpb.br (E.M.S.); cunhabrs@yahoo.com.br (B.R.C.d.S.); diego20coelho@hotmail.com (D.F.O.C.); gilbertoufrpe.zootecnia@gmail.com (G.d.C.S.); guilhermeleite33@hotmail.com (G.M.L.); rafael.lopes.soares@gmail.com (R.L.S.); alyne.123@hotmail.com (M.A.C.S.); nbv@academico.ufpb.br (N.B.V.); pauloctjunior@gmail.com (P.d.C.T.J.); pgabrielabgomes@hotmail.com (P.G.B.G.)

2 Department of Animal Science, Federal University of Bahia, Salvador 40170-110, Bahia, Brazil; luisfbp@gmail.com

3 Department of Animal Science, Federal University of Maranhao, Chapadinha 65500-000, Maranhão, Brazil; anderson.zanine@ufma.br

* Correspondence: nayssonzootecnista@gmail.com; Tel.: +55-8599997-9264

Simple Summary: Small ruminants fed on cactus pear exclusively in the diet may present nutritional disorders, especially diarrhea. This is due to the high moisture requirements present in this food, related to microbiological factors inherent to poor hygienic quality, such as handling and prolonged exposure of crushed palm to the air, which can cause greater ingestion by animals of certain bacterial groups with pathogenic potential. The aim of this research was to investigate the levels of cactus associated with buffel grass hay on the microbiological quality of diets and the influence on physiological parameters in sheep. Thus, this research revealed that the participation of buffel grass hay was able to reduce the contamination of bacteria that cause diarrhea and depress animal performance.

Abstract: This study aimed to evaluate the microbiological composition of cactus pear-based diets with increasing levels of buffel grass hay, and its effect on the blood and physiological parameters and occurrence of diarrhea in feedlot sheep. Four diets containing different percentages of buffel grass hay were tested. Diets were composed of forage cactus, buffel grass hay and concentrate, and the treatments were represented by different levels of hay in the dry matter of the feed: $7.5 \%$ buffel grass hay; $15 \%$ buffel grass hay; $30 \%$ buffel grass hay; and $45 \%$ buffel grass hay on a dry matter basis. There was a significant effect $(p=0.0034)$ of inclusion levels of buffel grass hay on fecal score. Only at the $45 \%$ inclusion level diarrhea was not observed, showing that the level of buffel grass affected more the animals than the collection period, although the collection period has affected the microbial counts. Probably there was a physiological adaptation of animals over time. There were significant changes $(p<0.0001)$ in the blood parameters of sheep. The reduction of the proportion of cactus and the inclusion of greater than $15 \%$ buffel grass hay, on a dry matter basis, provides less contamination of the diet and animal feces by enterobacteria, such as E. coli.

Keywords: non-fiber carbohydrates; diarrhea; pathogenic microorganisms; ruminants

\section{Introduction}

In semiarid regions that present irregular patterns in the distribution of rainfall at a certain time of the year, the performance of animals may be limited by forage availability. 
One way to circumvent this limitation is to provide concentrate feed for animals, and/or use forage plants adapted to climatic and soil conditions, such as cactus pear [1,2].

In this sense, the cactus pear is a plant with high adaptability and resistance to weather and that is present in several semiarid regions of the world.

As a food, the cactus pear is an excellent energy source, due to its high content of non-fiber carbohydrates, and is an excellent source of water, due to its moisture content [2]. Thus, the tendency of farms in the semiarid region is to use as much cactus pear as possible in rations.

In turn, the exclusive use of cactus pear in animal diets, can cause nutritional disorders to animals, such as diarrhea, foamy bloat and ruminal acidosis [3]. Several authors relate these nutritional disorders to low levels of physically effective neutral detergent fiber (NDFpe) in cactus pear $[4,5]$. However, the appearance of nutritional disorders in ruminants fed high levels of cactus pear is also related to microbiological factors regarding poor hygienic quality, such as handling and exposure of crushed cactus pear to air for a long time, which can provide a greater intake by animals of certain bacterial groups with pathogenic potential, for example, the order Enterobacteriales, responsible for diarrhea [4]. Considering that cactus pear is rich in water, when it is chopped and exposed to air for hours during the animal feeding it could allow microorganisms access to moisture and nutrients, leading to a microbial contamination.

Thus, it is important to use other sources fiber sources from hay or forage in diets based on cactus pear, as it implies in reducing the incidence of nutritional disorders not only by improving the NDFpe of the diet, but possibly also by reducing both moisture and soluble carbohydrate content [5].

Thus, buffel grass (Cenchrus ciliaris L.) can be an alternative, as it is one of the most cultivated grasses in arid and semiarid regions, mainly due to its tolerance and adaptability to low rainfall [6]. Among the ways to use the buffel grass, that the grass has favorable characteristics to be preserved as hay, as it has a high leaf:stem ratio, thin stems and narrow cuticle.

However, although there are several studies on the combination of buffel grass hay with cactus pear, aiming to improve animal performance, there are no studies on the relationship between nutritional disorders and the growth of microorganisms with pathogenic potential in diets with cactus pear.

In this context, this study aimed to evaluate the microbiological composition of cactus pear-based diets with increasing levels of buffel grass hay, and its effect on the blood and physiological parameters and occurrence of diarrhea in feedlot sheep.

\section{Materials and Methods}

\subsection{Place and Period of Execution of the Experiment}

The experiment was conducted on a private property located in the municipality of São José dos Cordeiros, between September and November 2020.

The municipality of São José dos Cordeiros is located in the central region of the state of Paraíba, Borborema Mesoregion and Western Cariri Microregion, with latitude: $7^{\circ} 23^{\prime} 26^{\prime \prime}$ S, Longitude: $36^{\circ} 48^{\prime} 30^{\prime \prime} \mathrm{W}$ and $529 \mathrm{~m}$ altitude. The climate of the region is classified as semiarid BSh, according to the Köppen classification, with average rainfall of $551.0 \mathrm{~mm}$ per year.

\subsection{Animal Management and Experimental Treatments}

For the experimental trial, 40 rams with non-descript breed with an initial body weight of $18 \mathrm{~kg} \pm 2.6 \mathrm{~kg}$ were used. In the period before the experiment, animals were weighed, vaccinated against Clostridiosis and treated against endo- and ectoparasites. Animals were housed in individual pens, measuring approximately $3 \mathrm{~m}^{2}$, with a feeding trough to supply the diet and a drinking fountain with unrestricted access to water. The experiment lasted 60 days, divided into ten days for the pre-experimental period for adaptation to the facilities and diets, and 50 days for data collection. Rations were based on cactus pear 
"Mexican Elephant Ear" (Opuntia stricta Haw) and buffel grass hay (Cenchrus ciliaris L.), both harvested one year after planting (Table 1).

Table 1. Chemical composition of ingredients used in the experimental diets on a dry matter basis.

\begin{tabular}{ccccccc}
\hline \multicolumn{7}{c}{ Ingredients } \\
\hline $\begin{array}{c}\text { Item } \mathbf{1} \\
\text { (g/kg DM) }\end{array}$ & Cactus & $\begin{array}{c}\text { Buffel Grass } \\
\text { Hay }\end{array}$ & Corn Bran & Soybean Meal & Cotton Pie & Urea \\
\hline DM $^{2}$ & 123.0 & 913.5 & 892.4 & 906.0 & 927.0 & 975.3 \\
CP & 44.0 & 38.3 & 94.7 & 400.0 & 202.7 & 281.0 \\
NFC & 518.9 & 50.5 & 647.8 & 342.3 & 148.5 & 0.0 \\
EE & 19.3 & 10.8 & 66.0 & 17.1 & 94.3 & 0.0 \\
MM & 118.0 & 79.2 & 16.4 & 64.8 & 46.8 & 2.1 \\
NDF & 299.8 & 821.2 & 175.1 & 175.8 & 507.7 & 0.0 \\
ADF & 184.2 & 486.0 & 38.9 & 86.6 & 276.8 & 0.0 \\
Cellulose & 141.3 & 376.1 & 34.3 & 81.8 & 245.5 & 0.0 \\
Hemicellulose & 115.1 & 302.8 & 90.0 & 69.3 & 207.3 & 0.0 \\
Lignin & 45.4 & 79.7 & 12.1 & 15.6 & 41.8 & 0.0 \\
\hline
\end{tabular}

${ }^{1} \mathrm{DM}=$ Dry Matter; CP = Crude protein; NFC = Non-fibrous carbohydrates; EE = Ethereal extract; MM; Mineral matter; $\mathrm{NDF}=$ Neutral detergent fiber; $\mathrm{ADF}=$ Acid detergent fiber. ${ }^{2}$ based on natural matter.

Animals were distributed in a completely randomized design, with four treatments and 10 replications. Four diets consisting of different levels of inclusion of buffel grass hay in the dry matter of the feed were evaluated: $7.5 \% \mathrm{FB}=7.5 \%$ buffel grass hay; $15 \%$ $\mathrm{FB}=15 \%$ buffel grass hay; $30 \% \mathrm{FB}=30 \%$ buffel grass hay; and $45 \% \mathrm{FB}=45 \%$ buffel grass hay on a dry matter (DM) basis. Diets were formulated to be isonitrogenous, and meet the requirements, according to the [7], of sheep with an average weight of $18 \mathrm{~kg}$, for a weight gain of $200 \mathrm{~g} /$ day (Table 2).

Table 2. Proportions of ingredients and chemical composition of experimental diets for sheep fed different levels of buffel grass hay, on a dry matter basis.

\begin{tabular}{lcccc}
\hline & \multicolumn{3}{c}{ Diets $^{\mathbf{1}}$} \\
\hline Item (g/kg DM) & $\mathbf{7 . 5 \%}$ & $\mathbf{1 5 \%}$ & $\mathbf{3 0} \%$ & $\mathbf{4 5 \%}$ \\
\hline Cactus pear & 409.3 & 336.6 & 191.2 & 45.8 \\
Buffel grass hay & 72.7 & 145.4 & 290.8 & 436.2 \\
Soybean meal & 64.6 & 64.6 & 64.6 & 64.6 \\
Corn bran & 235.6 & 235.6 & 235.6 & 235.6 \\
Cotton pie & 178.4 & 178.3 & 178.1 & 178.0 \\
Urea & 8.8 & 8.9 & 9.0 & 9.2 \\
Mineral nucleus & 16.2 & 16.2 & 16.2 & 16.2 \\
Ammonium chloride & 13.5 & 13.5 & 13.5 & 13.5 \\
Ammonium sulfate & 1.0 & 1.0 & 1.0 & 1.0 \\
\hline Item (g/kg DM) & & Chemical Composition & \\
\hline DM ${ }^{3}$ & 248.7 & 285.6 & 406.2 & 703.0 \\
CP & 141.3 & 142.0 & 141.7 & 142.3 \\
NFC & 442.0 & 409.9 & 347.0 & 283.4 \\
EE & 42.2 & 41.5 & 40.3 & 39.0 \\
MM & 48.9 & 43.2 & 31.8 & 20.4 \\
NDF & 325.6 & 363.4 & 439.2 & 514.9 \\
\hline
\end{tabular}

${ }^{1} 7.5 \%$ Buffel grass hay; 15\% Buffel hay; 30\% Buffel hay; 45\% Buffel hay based on dry matter; ${ }^{2}$ DM = Dry Matter; $\mathrm{CP}=$ Crude protein NFC $=$ Non-fibrous carbohydrates; $\mathrm{EE}=$ Ethereal extract; $\mathrm{MM}=$ Mineral matter; $\mathrm{NDF}=$ Neutral detergent fiber. ${ }^{3}$ Based on natural matter.

\subsection{Food Management and Consumption}

Feed was supplied ad libitum in two equal daily portions, at 08:00 and 16:00 h, weighed and adjusted, allowing $10 \%$ leftovers. Leftovers were daily weighed to control the intake of 
dry matter and other nutrients by the animals. Leftovers were collected before supplying the feed, both in the morning and in the afternoon.

Dry matter (DM) intake occurred with the daily weighing of the diet offered and the leftovers between days 15 and 49 of the experimental period. Dry matter intake (DMI) was calculated from the difference between the ingested amount of feed and leftovers, both on a DM basis. For this, samples of food, diets and leftovers were collected every seven days of the experimental period, to determine the dry matter content.

\subsection{Food Sampling and Analysis}

Chemical analyses were performed on samples of ingredients and feeds in the food analysis laboratory of the Semiarid National Institute (INSA), Campina Grande, state of Paraíba. For this purpose, samples were analyzed for dry matter (DM; method 934.01), mineral matter (MM; method 942.05), crude protein (CP; method 954.01), ether extract (EE; method 920.39) and lignin (method 973.18) were determined, according to [8]. Neutral detergent fiber (NDF) and acid detergent fiber (ADF) were determined according to the methodology proposed by [9], using the ANKOM fiber analyzer (ANKOM200 Fiber Analyzer-ANKOM Technology Corporation, Fairport, NY, USA).

The non-fiber carbohydrate (NFC) content of ingredients and feed was calculated using the equations recommended by [10]: $=100-(\% \mathrm{CP}+\% \mathrm{NDF} c \mathrm{~F}+\% \mathrm{EE}+\% \mathrm{MM})$.

\subsection{Blood Collections, Serum and Physiological Parameters}

Blood was collected from all sheep by puncturing the jugular vein using Vacutainer tubes containing EDTA (ethylenediaminetetraacetic acid) (0.1 mL 10\% EDTA) with a volume of $5 \mathrm{~mL}$ each, on the 1st, 6th and 26th day of the experimental period. Collections were carried out before the morning meal and sent immediately to the laboratory for complete blood count and identification of microangiopathic hemolytic anemia due to verotoxins, considering as standard values of the experiment those found in the blood analyzed in the 1 st day of the experimental period.

The blood count evaluated: Hemoglobin $(\mathrm{Hb})$ (cyanomet hemoglobin described by [11], Mean corpuscular volume (MCV), Mean globular hemoglobin concentration (CHCM), Platelets, Total plasma protein (TPP) by refractometry, Fibrinogen (FP), Leukocytes (hemocytometer), Rods, Segmented, eosinophils and monocytes [12]

On the second and 22nd of the experimental period, at 9:00 am, the physiological variables of all animals were collected. The respiratory rate was determined by counting the flank movements for $15 \mathrm{~s}$, this result was multiplied by four to obtain the number of respiratory movements per minute. Rectal temperature was measured using a clinical thermometer inserted into the rectum for one minute, with individual readings, followed by notes. Skin surface temperatures on the nape, shoulder, leg and belly were also measured using an infrared thermometer, at a distance of $30 \mathrm{~cm}$ from the animal's surface, directed transversely to the specific location.

\subsection{Fecal Score and Microbial Population Count}

The fecal score of the animals was determined according to consistency, which varies from 0 (normal consistency) to 4 (watery consistency), according to the [13].

On the 1st and 21st day of the experimental period, samples were taken from feces (directly from the rectum) and leftovers (removed from the troughs) for microbiological evaluation, in which the growth of enterobacteriaceae and E. coli (fecal contamination indicator). For this, samples were taken and immediately sent to the laboratory in a Styrofoam box with ice.

To evaluate the microbial populations, $25 \mathrm{~g}$ feces and dietary leftovers were collected in the trough, added in two hundred and twenty-five milliliters $(225 \mathrm{~mL})$ of $0.1 \%$ sterile buffered peptone water solution. Through the selective technique of culture medias, violetred bile lactose agar was used for growth, for the cultivation of enterobacteriaceae and E.M.B Levine agar for the cultivation of E. coli. From the first dilution, new serial dilutions 
were made, the material from each treatment was grown in sterile Petri dishes using the pour-plate method with the respective culture media, in duplicate, and incubated in a bacteriological incubator at $36^{\circ} \mathrm{C}$ for $24 \mathrm{~h}$.

Plates for counting were those with values between 30 and 300 CFU (colony forming units), considering the dilution. Colonies of enterobacteria showed a circular shape and pink coloration, and E. coli showed a similar shape, but with a metallic green color.

\subsection{Statistical Analysis}

\subsubsection{Blood, Microbiological Count and Physiological Parameters}

The means of the different periods were compared by Tukey's Test using the SAS ${ }^{\circledR}$ software. A 5\% significance level was used in all hypothesis tests. Given the correlation between the values obtained from the same animal in different periods of evaluation, analysis of variance with repeated measures over time was used. The choice of the covariance matrix for this analysis was made from the analysis of different matrices and the matrix that resulted in the lowest BIC (Bayesian Information Criterion) was selected. When the effect of treatment was significant, their degrees of freedom were broken down into linear, quadratic and cubic contrasts. A mixed model was used, which can be described as

$$
Y i j k l=\mu+A i+X j+P k+(X P)+j k+\varepsilon i j k l
$$

where Yijkl is the record of the variable of interest; $\mathrm{Ai}$ is the random effect of the i-th animal, where $i=38$ levels in the analysis of blood count data and $i=20$ levels in the analysis of micobiology data; $X j$ is the fixed effect of the $j$ th level of buffel grass hay, where $j=(1, \ldots, 4)$, $\mathrm{Pk}$ is the fixed effect of the kth period, where for hemogram variables $\mathrm{k}=(1, \ldots, 3)$, while for microbiology variables $\mathrm{k}=(1,2) ;(\mathrm{XP}) \mathrm{jk}$ is the fixed effect of the interaction between the jth buffel grass hay and the kth period; and $\varepsilon$ ijkl is the random effect of the residual.

\subsubsection{Fecal Score}

For the analysis of fecal score, as it is a discrete ordinal variable, it was decided to implement a generalized linear model. This model can be described as

$$
Y i j k=\mu+X i+P j+(X P)+i j+\varepsilon i j k
$$

where Yijk is the fecal score record; $X i$ is the fixed effect of the $i$-th level of buffel grass hay; $\mathrm{Pj}$ is the fixed effect of the $\mathrm{j}$-th period; $(\mathrm{XP})$ ij is the fixed effect of the interaction between the $\mathrm{i}$-th\% buffel grass hay and the $\mathrm{j}$-th period; and iijk is the random effect of the residual. This model was fitted with a multinomial distribution and the CUMLOGIT option as a link. In this analysis, 5\% was also assumed as the significance level.

\section{Results}

An effect of interaction of collection period and buffel grass hay levels was detected on the counts of Enterobacteriaceae $(p<0.0001)$ and E. coli $(p=0.0043)$ (Table 3). Both on the 1st and 21st day, there was a cubic effect of the levels of buffel grass hay on the count of Enterobacteriaceae in the leftovers (Figure 1). There was also a quadratic effect of buffel grass hay levels on E. coli count on day 1 (Figure 2). The lowest E. coli count in the leftovers occurred when the animals consumed 32.7\% buffel grass hay (Figure 2). There was no significant difference in the E. coli count in the leftovers on the 21st day, with a mean value of $4.45 \log \mathrm{CFU} / \mathrm{g}$. 
Table 3. Bacteria count in leftovers and feces of sheep fed levels of buffel grass hay and cactus pear.

\begin{tabular}{|c|c|c|c|c|c|c|c|c|c|c|}
\hline \multirow{3}{*}{$\log \mathrm{CFU} / \mathrm{g}^{1}$} & \multirow{3}{*}{$\begin{array}{c}\text { Levels Buffel Grass } \\
\text { Hay \% }\end{array}$} & \multicolumn{2}{|c|}{ Period (Days) } & \multirow{3}{*}{$\begin{array}{l}\text { Overall Average } \\
\text { (BH) }\end{array}$} & \multicolumn{3}{|c|}{$\mathrm{F}^{2}$ Test $p$-Value } & \multirow{2}{*}{\multicolumn{3}{|c|}{$\begin{array}{c}p \text {-Value } \\
\mathrm{BBH}^{3}\end{array}$}} \\
\hline & & \multirow{2}{*}{$1^{\circ}$} & \multirow{2}{*}{$21^{\circ}$} & & \multirow{2}{*}{ BH } & \multirow{2}{*}{$\mathbf{P}$} & \multirow{2}{*}{ Interaction (BH x P) } & & & \\
\hline & & & & & & & & L & $\mathbf{Q}$ & $\mathrm{C}$ \\
\hline \multirow[t]{5}{*}{ Enterobacteria, Leftovers } & 7.5 & $7.97 \mathrm{a} \pm 0.51$ & $5.46 \mathrm{~b} \pm 0.51$ & $6.72 \pm 0.49$ & \multirow[t]{5}{*}{0.0052} & \multirow[t]{5}{*}{$<0.0001$} & \multirow[t]{5}{*}{$<0.0001$} & 0.3670 & 0.0002 & 0.0077 \\
\hline & 15 & $6.64 a \pm 0.51$ & $4.41 \mathrm{~b} \pm 0.51$ & $6.02 \pm 0.49$ & & & & 0.5414 & 0.1173 & 0.0498 \\
\hline & 30 & $5.75 \mathrm{a} \pm 0.51$ & $5.39 \mathrm{a} \pm 0.51$ & $5.57 \pm 0.49$ & & & & & & \\
\hline & 45 & $3.87 \mathrm{a} \pm 0.51$ & $3.79 a \pm 0.51$ & $3.83 \pm 0.49$ & & & & & & \\
\hline & Overall Average (P) & $6.06 \pm 0.25$ & $5.01 \pm 0.25$ & & & & & & & \\
\hline \multirow{4}{*}{ E. coli, Leftovers } & 7.5 & $6.37 \mathrm{a} \pm 0.27$ & $4.54 \mathrm{~b} \pm 0.27$ & $5.46 \pm 0.23$ & \multirow[t]{4}{*}{0.0502} & \multirow[t]{4}{*}{$<0.0001$} & \multirow[t]{4}{*}{0.0043} & 0.5584 & 0.0002 & 0.6641 \\
\hline & 30 & $4.84 \mathrm{a} \pm 0.27$ & $4.57 \mathrm{a} \pm 0.27$ & $4.71 \pm 0.23$ & & & & & & \\
\hline & 45 & $5.08 \mathrm{a} \pm 0.27$ & $4.25 \mathrm{a} \pm 0.27$ & $4.66 \pm 0.23$ & & & & & & \\
\hline & Overall Average $(\mathrm{P})$ & $5.63 \pm 0.14$ & $4.45 \pm 0.14$ & & & & & & & \\
\hline \multirow[t]{5}{*}{ Enterobacteria, Feces } & 7.5 & $8.24 \pm 0.19$ & $5.41 \pm 0.19$ & $6.83 \pm 0.15$ & \multirow[t]{5}{*}{0.7663} & \multirow[t]{5}{*}{$<0.0001$} & \multirow[t]{5}{*}{0.3328} & \multirow[t]{5}{*}{0.7191} & \multirow[t]{5}{*}{0.3344} & \multirow[t]{5}{*}{0.8749} \\
\hline & 15 & $8.03 \pm 0.19$ & $5.50 \pm 0.19$ & $6.76 \pm 0.15$ & & & & & & \\
\hline & 30 & $7.73 \pm 0.19$ & $5.50 \pm 0.19$ & $6.62 \pm 0.15$ & & & & & & \\
\hline & 45 & $8.03 \pm 0.19$ & $5.32 \pm 0.19$ & $6.67 \pm 0.15$ & & & & & & \\
\hline & Overall Average (P) & $8.01 \mathrm{a} \pm 0.09$ & $5.43 \mathrm{~b} \pm 0.09$ & & & & & & & \\
\hline \multirow{4}{*}{ E. coli, Feces } & 7.5 & $6.73 \pm 0.22$ & $4.76 \pm 0.22$ & $5.71 \pm 0.15$ & \multirow{4}{*}{0.5140} & \multirow{4}{*}{$<0.0001$} & \multirow{4}{*}{$<0.1243$} & \multirow{4}{*}{0.8374} & \multirow{4}{*}{0.3487} & 0.2521 \\
\hline & 15 & $7.10 \pm 0.22$ & $4.32 \pm 0.22$ & $6.00 \pm 0.15$ & & & & & & \\
\hline & 45 & $7.25 \pm 0.22$ & $4.24 \pm 0.22$ & $5.75 \pm 0.15$ & & & & & & \\
\hline & Overall Average (P) & $7.06 \mathrm{a} \pm 0.11$ & $4.54 \mathrm{~b} \pm 0.11$ & & & & & & & \\
\hline
\end{tabular}

${ }^{1} \mathrm{CFU}=$ Colony forming units; ${ }^{2} \mathrm{BH}=$ Buffel grass hay; $\mathrm{P}=$ collection periods $;{ }^{3} \mathrm{~L}=$ Linear, $\mathrm{Q}=$ quadratic and $\mathrm{C}=$ cubic; $5 \%$ significance level. The means followed by different letters on the same line differ from each other by the Tukey test at $5 \%$ significance.However, Table 3 and Figures 1 and 2 show that in leftovers from animals consuming $45 \%$ buffel grass hay, there was greater growth of Enterobacteriaceae and E. coli than in leftovers from animals consuming intermediate levels of buffel grass hay (15 and $30 \%)$. 


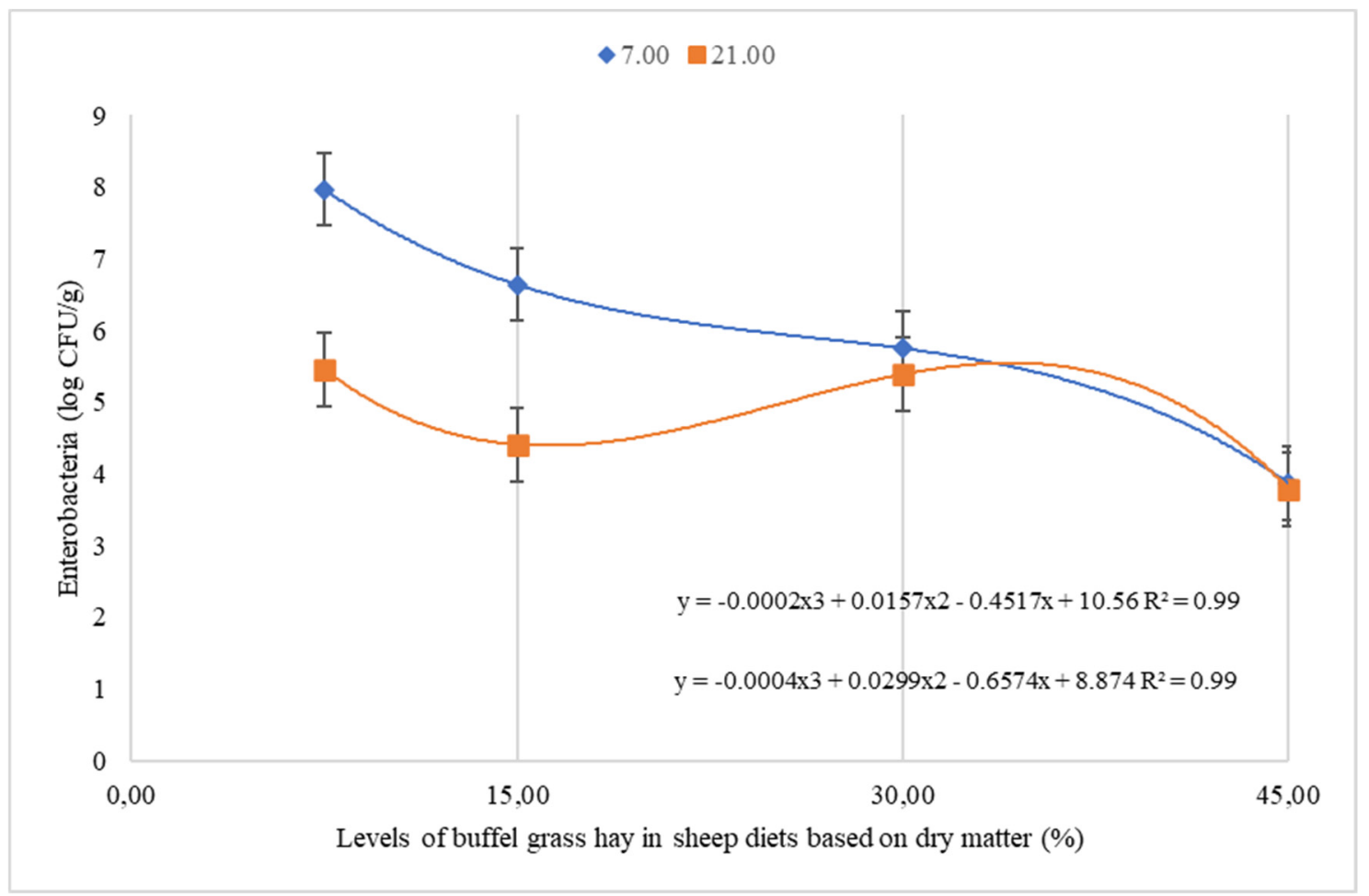

Figure 1. Growth of Enterobacteriaceae in the leftovers of sheep fed levels of buffel grass hay and cactus pear. $\mathrm{CFU}=$ colony forming unit. $7.00=7$ th day and $21.00=21$ st day.

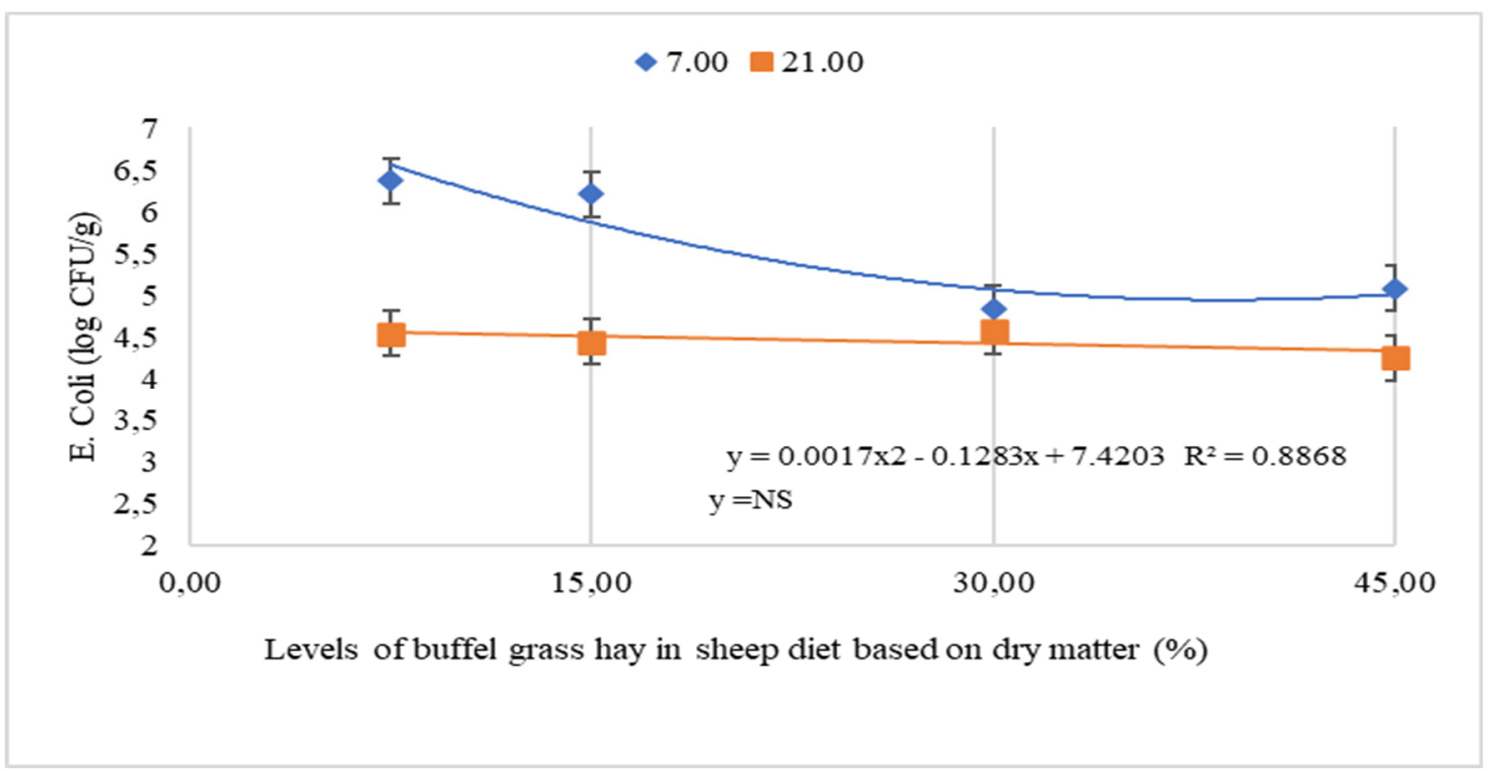

Figure 2. Growth of Escherichia coli in the leftovers of sheep fed levels of buffel grass hay and cactus pear. $\mathrm{CFU}=$ colony forming unit. $7.00=7$ th day and $21.00=21$ st day.

On the first day of collection, leftovers of animals consuming the lowest levels of buffel grass hay $(7.5 \%$ and $15 \%)$ had the highest count values for both Enterobacteriaceae (7.97 log CFU/g and 6.37 log CFU/g) and E. coli (6.64 log CFU/g and 6.21 log CFU/g) compared to the 21st day, with values of $5.46 \mathrm{log} \mathrm{CFU} / \mathrm{g}$ for Enterobacteriaceae and $4.54 \log$ CFU/g for E. coli (7.5\% buffel hay) and $4.41 \log$ CFU/g for Enterobacteriaceae and $4.44 \mathrm{log}$ CFU / g for E. coli (15\% buffel hay). The counts in the leftovers of animals consuming $30 \%$ and $45 \%$ buffel grass hay did not differ between collection periods, with mean values 
of $5.57 \log \mathrm{CFU} / \mathrm{g}$ and $3.83 \log \mathrm{CFU} / \mathrm{g}$ for Enterobacteriaceae and $4.71 \mathrm{log} \mathrm{CFU} / \mathrm{g}$ and $4.66 \log \mathrm{CFU} / \mathrm{g}$ for E. coli, respectively.

As for feces, there was a significant difference $(p<0.0001)$ in the counts of Enterobacteriaceae and E. coli (Table 3). The highest counts were found in the 1st collection period for both Enterobacteriaceae (8.01 $\log$ CFU/g) and E. coli (7.06 log CFU/g). There was no effect of diets on the growth of Enterobacteriaceae and E. coli in animal feces, with mean values of $6.72 \log \mathrm{CFU} / \mathrm{g}$ and $5.73 \log \mathrm{CFU} / \mathrm{g}$, respectively.

There was no effect of interaction $(p=0.9311)$ on the fecal score of the animals (Table 4$)$. However, there was a significant effect $(p=0.0034)$ of the levels of buffel grass hay on this variable (Table 4 ). Animals fed $7.5 \%$ and $15 \%$ buffel grass hay presented the highest probabilities of score two, with averages of $70.7 \%$ and $63.2 \%$, respectively. Animals fed $30 \%$ buffel grass hay had higher probability values in score one. Animals fed $45 \%$ buffel grass hay scored zero in $100 \%$ samples.

Table 4. Dry matter intake (DMI) and probabilities of occurrence of fecal scores of sheep fed levels of buffel grass hay and cactus pear.

\begin{tabular}{|c|c|c|c|c|c|c|c|}
\hline \multirow{3}{*}{ Score } & \multicolumn{4}{|c|}{ Levels of Buffel Grass Hay, \% } & \multicolumn{3}{|c|}{$p$-Value } \\
\hline & $7.5 \mathrm{c}$ & $15 \mathrm{c}$ & $30 \mathrm{~b}$ & $45 a$ & $\mathrm{BH}^{1}$ & $\mathbf{P}^{2}$ & $\mathrm{BH} \times \mathrm{P}^{3}$ \\
\hline & \multicolumn{4}{|c|}{$\%$} & & & \\
\hline 0 & 2.6 & 3.8 & 2.8 & 100 & \multirow{4}{*}{0.0034} & \multirow{4}{*}{0.9991} & \multirow{4}{*}{0.9311} \\
\hline 1 & 20.2 & 26.5 & 78.6 & 0 & & & \\
\hline 2 & 70.7 & 63.2 & 12.1 & 0 & & & \\
\hline \multirow[t]{3}{*}{3} & 6.5 & 6.5 & 6.5 & 0 & & & \\
\hline & \multicolumn{4}{|c|}{ Levels of Buffel Grass Hay, \% } & \multirow{2}{*}{$\mathrm{EP}^{4}$} & \multicolumn{2}{|c|}{$p$-Value } \\
\hline & 7.5 & 15 & 30 & 45 & & $\mathbf{L}$ & $\mathbf{Q}$ \\
\hline DMI, kg/dia & 1.05 & 1.38 & 1.30 & 1.07 & 0.235 & 0.6262 & 0.0101 \\
\hline
\end{tabular}

The quadratic effect of the levels of buffel grass hay on the dry matter intake of the animals is observed, in which the maximum consumption of sheep is estimated at the level of $25.3 \%$ of buffel grass hay (Table 4 ).

There was no effect on the physiological variables: rectal temperature $(p=0.953)$, nape temperature $(p=0.263)$, shoulder temperature $(p=0.246)$, leg temperature $(p=0.257)$, and heart rate $(p=0.496)$. Probably, there was an adaptation of the animals to a high load of microorganisms with pathogenic potential (Table 5), which can be proven by the non-significance of the levels of buffel grass hay and the period on most of the physiological parameters of the animals (Table 5).

There was no effect of buffel grass hay levels in the diet and collection day on mean corpuscular volume (VHCM) and platelets, with mean values of $30.5 \mathrm{fL}$ and 776,070.75 $\mu \mathrm{L}$, respectively (Table 6).

There was an effect of the collection period $(p<0.0001)$. On the 21st day $\left(9.45 \times 10^{6} \mathrm{~mm}^{3}\right)$, there was a higher concentration of erythrocytes than on the 1st day $\left(7.33 \times 10^{6} \mathrm{~mm}^{3}\right)$ and on the 7th day $\left(7.90 \times 10^{6} \mathrm{~mm}^{3}\right)$. However, there was no effect of buffel grass hay levels on erythrocyte concentrations $(p=0.4139)$ with a mean value of $8.22 \times 10^{6} \mathrm{~mm}^{3}$.

Hemoglobin values had a significant effect $(p<0.0001)$ for the collection periods and there was an effect of interaction of hay levels with collection periods $(p<0.0001)$. Animals consuming $7.5 \%$ buffel grass hay had higher hemoglobin concentrations on the 21 st day $(9.24 \mathrm{~g} / \mathrm{dL}$ and $9.43 \mathrm{~g} / \mathrm{dL})$ than on the 1 st day $(7.17 \mathrm{~g} / \mathrm{dL}$ and $8.10 \mathrm{~g} / \mathrm{dL})$. Animals consuming $15 \%$ and $30 \%$ buffel grass hay had higher hemoglobin concentration on the 21 st day. There was no effect of period on the hemoglobin concentration in animals fed $45 \%$ buffel grass hay, with a mean value of $8.26 \mathrm{~g} / \mathrm{dL}$. 
Table 5. Isolated effects for physiological parameters and interaction effect for belly temperature of sheep fed levels of buffel grass hay and cactus pear.

\begin{tabular}{|c|c|c|c|c|c|c|c|}
\hline \multirow{2}{*}{ Variables } & \multicolumn{4}{|c|}{ Levels of Buffel Grass Hay (\%) } & \multirow{2}{*}{ Average } & \multirow{2}{*}{ SEM } & \multirow{2}{*}{$p$-Value } \\
\hline & 7.5 & 15 & 30 & 45 & & & \\
\hline T. ${ }^{1}$ rectal $\left({ }^{\circ} \mathrm{C}\right)$ & 39.12 & 39.11 & 39.10 & 39.05 & 39.09 & 0.096 & 0.953 \\
\hline T. of the nape $\left({ }^{\circ} \mathrm{C}\right)$ & 35.99 & 36.56 & 36.55 & 37.24 & 36.58 & 0.439 & 0.263 \\
\hline T. of palette $\left({ }^{\circ} \mathrm{C}\right)$ & 34.29 & 33.94 & 34.28 & 34.86 & 34.34 & 0.325 & 0.257 \\
\hline T. of ham $\left({ }^{\circ} \mathrm{C}\right)$ & 33.46 & 32.24 & 34.00 & 34.48 & 33.54 & 0.814 & 0.246 \\
\hline $\mathrm{RR}^{2}\left(\right.$ mov.min $\left.^{-1}\right)$ & 25.72 & 25.55 & 25.22 & 24.89 & 25.35 & 1.296 & 0.496 \\
\hline \multirow{6}{*}{$\begin{array}{l}\text { Belly temperature } \\
\qquad\left({ }^{\circ} \mathrm{C}\right)\end{array}$} & \multirow{2}{*}{$\begin{array}{c}\text { Levels of Buffel } \\
\text { Grass Hay \% }\end{array}$} & \multicolumn{2}{|c|}{ Period/Day } & \multirow{2}{*}{ SEM } & \multicolumn{3}{|c|}{$p$-Value } \\
\hline & & $1^{\circ}$ & $21^{\circ}$ & & BH $^{3}$ & $\mathbf{P}$ & BH $\times$ P \\
\hline & 7.5 & $36.24 \mathrm{Aa}$ & $35.40 \mathrm{Ba}$ & \multirow{4}{*}{0.243} & \multirow{4}{*}{0.393} & \multirow{4}{*}{0.275} & \multirow{4}{*}{0.031} \\
\hline & 15 & $36.79 \mathrm{Aa}$ & $36.79 \mathrm{Aa}$ & & & & \\
\hline & 30 & $36.40 \mathrm{Aa}$ & $36.75 \mathrm{Aa}$ & & & & \\
\hline & 45 & $36.66 \mathrm{Aa}$ & $36.99 \mathrm{Aa}$ & & & & \\
\hline
\end{tabular}

Means followed by the same capital letter, in the columns, and lowercase in the rows, do not differ by Tukey's test at 0.05 probability: SEM: standard error of the mean; ${ }^{3} \mathrm{BH}=$ Treatment; $\mathrm{P}=$ Period; $\mathrm{BHxP}=$ interaction effect; ${ }^{1} \mathrm{~T}$. = Temperature; ${ }^{2} \mathrm{FR}=$ Respiratory rate.

Hematocrit values showed a significant difference $(p<0.0001)$ for the collection periods, with an increase in the amount of hematocrit on the 21st day compared to the 1st and 7th day (Table 6).

There was a significant effect $(p<0.0001)$ for the collection periods and interaction of buffel grass hay levels with collection periods $(p=0.0092)$ on the mean corpuscular hemoglobin concentration (CHCM). Mean values of $\mathrm{CHCM}$ of animals fed $7.5 \%$ buffel on the 1st day $(30.18 \mathrm{~g} / \mathrm{dL})$ were lower than the 7 th $(33.07 \mathrm{~g} / \mathrm{dL})$ and $21 \mathrm{st}(32.90 \mathrm{~g} / \mathrm{dL})$ days. With respect to animals fed the other levels of buffel grass hay, there was no effect of period on this variable.

There was a significant effect $(p=0.0106)$ for the collection periods and interaction of the levels of buffel grass hay with the collection periods $(p=0.0090)$ for leukocytes (Table 6). Animals receiving 15\% buffel grass hay had higher concentrations of leukocytes on the 7th $(8011.11 \mu \mathrm{L})$ and $21 \mathrm{st}(7955.56 \mu \mathrm{L})$ days when compared to the same animals on the 1 st $(5277.78 \mu \mathrm{L})$ day of collection. There was no effect of period on leukocytes of animals consuming $7.5 ; 30$ and $45 \%$ buffel grass hay, with mean values of $7349.73 \mu \mathrm{L} ; 7185.19 \mu \mathrm{L}$ and $8769.58 \mu \mathrm{L}$, respectively.

The values of segmented showed significant differences for the collection period $(p<0.0001)$ and interaction $(p=0.0083)$. Animals consuming $15 \%$ buffel grass hay had higher segmented values on the 7th day $(8011.11 \mu \mathrm{L})$ and 21 st day $(7955.56 \mu \mathrm{L})$ when compared to the 1 st day $(5277.78 \mu \mathrm{L})$. Animals fed $45 \%$ buffel grass hay had higher segmented values on the 7th day when compared to the 21st day. Animals receiving 7.5 and $30 \%$ buffel grass hay had similar segmented values in the different collection days.

There was interaction $(p<0.0001)$ on eosinophils, and animals receiving $30 \%$ on the 21st day had the highest blood eosinophil levels (Table 6). Animals from other treatments had similar eosinophil values on the 1st, 7 th and 21st day. There was also a quadratic effect of buffel grass hay levels on eosinophil values on the 1st day and cubic effect on the 7th and 21st days.

There was no effect of interaction of buffel grass hay levels with period in relation to lymphocytes. However, there was a quadratic effect of levels of buffel grass hay on this parameter, with a minimum value of $18.7 \%$ buffel grass hay (Figure 3 ). There was also an effect of period on lymphocytes, in which there was a lower concentration of lymphocytes on the 7th day when compared to the 1st and 21st days. 
Table 6. Blood parameters of sheep fed levels of buffel grass hay and cactus pear.

\begin{tabular}{|c|c|c|c|c|c|c|c|c|c|c|c|}
\hline \multirow{3}{*}{ Characteristic } & \multirow{3}{*}{$\begin{array}{c}\text { Levels Buffel Grass } \\
\text { Hay \% }\end{array}$} & \multicolumn{3}{|c|}{ Period (Days) } & \multirow{3}{*}{$\begin{array}{l}\text { Overall Average } \\
\text { (BH) }\end{array}$} & \multicolumn{3}{|c|}{$\mathrm{F}^{1}$ Test $p$-Value } & \multirow{2}{*}{\multicolumn{3}{|c|}{$\begin{array}{c}p \text {-Value }{ }^{2} \\
\% \mathrm{BH}\end{array}$}} \\
\hline & & \multirow{2}{*}{$1^{\circ}$} & \multirow{2}{*}{$7^{\circ}$} & \multirow{2}{*}{$21^{\circ}$} & & \multirow{2}{*}{ BH } & \multirow{2}{*}{$\mathbf{P}$} & \multirow{2}{*}{ Interaction $(\mathrm{BH} \times \mathrm{P})$} & & & \\
\hline & & & & & & & & & L & $\mathbf{Q}$ & $\mathrm{C}$ \\
\hline \multirow{5}{*}{ Erythrocyte, $\mathrm{mm}^{3}$} & 7.5 & $6.73 \pm 0.87$ & $7.07 \pm 0.87$ & $8.55 \pm 0.87$ & $7.45 \pm 0.75$ & 0.4139 & $<0.0001$ & 0.3695 & 0.5713 & 0.1404 & 0.5182 \\
\hline & 15 & $5.84 \pm 0.92$ & $7.73 \pm 0.92$ & $9.86 \pm 0.92$ & $7.81 \pm 0.79$ & & & & & & \\
\hline & 30 & $9.04 \pm 0.97$ & $8.69 \pm 0.95$ & $9.96 \pm 0.92$ & $9.23 \pm 0.81$ & & & & & & \\
\hline & 45 & $7.68 \pm 0.87$ & $8.10 \pm 0.87$ & $9.27 \pm 0.90$ & $8.35 \pm 0.76$ & & & & & & \\
\hline & Overall Average $(\mathrm{P})$ & $7.33 \mathrm{~b} \pm 0.50$ & $7.90 \mathrm{~b} \pm 0.51$ & $9.45 \mathrm{a} \pm 0.35$ & & & & & & & \\
\hline \multirow[t]{4}{*}{ Hemoglobin, g/dL } & 7.5 & $7.17 \mathrm{~b} \pm 0.41$ & $8.20 \mathrm{ab} \pm 0.43$ & $9.24 \mathrm{a} \pm 0.43$ & $8.20 \pm 0.36$ & 0.1888 & $<0.0001$ & $<0.0001$ & 0.2456 & 0.0628 & 0.8732 \\
\hline & 30 & $8.10 \mathrm{~b} \pm 0.43$ & $7.92 b \pm 0.43$ & $9.43 a \pm 0.43$ & $8.76 \pm 0.36$ & & & & & & \\
\hline & 45 & $8.62 b \pm 0.43$ & $8.63 b \pm 0.41$ & $9.02 b \pm 0.43$ & $8.26 \pm 0.34$ & & & & & & \\
\hline & Overall Average $(\mathrm{P})$ & $7.45 \pm 0.21$ & $8.18 \pm 0.21$ & $9.19 \pm 0.22$ & & & & & & & \\
\hline \multirow[t]{5}{*}{ Hematocrit, \% } & 7.5 & $19.36 \pm 2.45$ & $20.78 \pm 2.45$ & $25.90 \pm 2.45$ & $23.28 \pm 2.30$ & 0.4201 & $<0.0001$ & 0.1726 & 0.5145 & 0.1610 & 0.4890 \\
\hline & 15 & $17.60 \pm 2.59$ & $22.58 \pm 2.59$ & $29.68 \pm 2.59$ & $27.23 \pm 2.33$ & & & & & & \\
\hline & 30 & $26.27 \pm 2.67$ & $24.91 \pm 2.67$ & $30.51 \pm 2.59$ & $24.46 \pm 2.19$ & & & & & & \\
\hline & 45 & $22.45 \pm 2.45$ & $23.03 \pm 2.45$ & $27.90 \pm 2.51$ & $22.01 \pm 2.19$ & & & & & & \\
\hline & Overall Average $(\mathrm{P})$ & $21.42 \mathrm{~b} \pm 1.27$ & $22.83 \mathrm{~b} \pm 1.27$ & $28.50 \mathrm{a} \pm 1.27$ & & & & & & & \\
\hline \multirow[t]{4}{*}{$\mathrm{CHCM}^{3}, \mathrm{~g} / \mathrm{dL}$} & 7.5 & $30.18 b \pm 0.68$ & $33.07 \mathrm{a} \pm 0.66$ & $32.90 \mathrm{a} \pm 0.66$ & $31.52 \pm 0.55$ & 0.4230 & $<0.0001$ & 0.0092 & 0.2556 & 0.9691 & 0.2186 \\
\hline & 15 & $31.12 b \pm 0.69$ & $32.51 b \pm 0.69$ & $30.92 b \pm 0.69$ & $31.21 \pm 0.57$ & & & & & & \\
\hline & 45 & $32.97 b \pm 0.66$ & $33.16 b \pm 0.66$ & $31.08 \mathrm{~b} \pm 0.68$ & $32.05 \pm 0.53$ & & & & & & \\
\hline & Overall Average $(\mathrm{P})$ & $31.27 \pm 0.34$ & $32.59 \pm 0.34$ & $31.52 \pm 0.34$ & & & & & & & \\
\hline \multirow[t]{5}{*}{ Leukocytes, $\mu \mathrm{L}$} & 7.5 & $7020.00 \mathrm{~b} \pm 765.81$ & $7510.00 \mathrm{~b} \pm 765.81$ & $7519.18 b \pm 765.81$ & $7349.73 \pm 673.29$ & 0.2666 & 0.0106 & 0.0090 & 0.4417 & 0.2737 & 0.1508 \\
\hline & 15 & $5277.78 b \pm 807.24$ & $8011.11 \mathrm{a} \pm 807.24$ & $7955.56 \mathrm{a} \pm 807.24$ & $7081.48 \pm 706.89$ & & & & & & \\
\hline & 30 & $7266.67 b \pm 807.24$ & $7166.67 b \pm 807.24$ & $7122.22 b \pm 807.24$ & $7185.19 \pm 706.89$ & & & & & & \\
\hline & 45 & $8930.00 b \pm 765.81$ & $9488.74 b \pm 780.49$ & $7890.00 \mathrm{~b} \pm 765.81$ & $8769.58 \pm 672.49$ & & & & & & \\
\hline & Overall Average $(\mathrm{P})$ & $7123.61 \pm 393.40$ & $8044.13 \pm 395.20$ & $7621.74 \pm 395.96$ & & & & & & & \\
\hline \multirow[t]{5}{*}{ Segmented, $\mu \mathrm{L}$} & 7.5 & $4339.70 \mathrm{~b} \pm 471.60$ & $4716.10 \mathrm{~b} \pm 471.60$ & $4361.00 \mathrm{~b} \pm 471.60$ & $4472.27 \pm 409.58$ & 0.5301 & $<0.0001$ & 0.0083 & 0.5195 & 0.6331 & 0.2173 \\
\hline & 15 & $3342.78 \mathrm{~b} \pm 497.11$ & $4791.34 \mathrm{ab} \pm 512.75$ & $4891.44 \mathrm{a} \pm 497.11$ & $4341.85 \pm 433.77$ & & & & & & \\
\hline & 30 & $3094.73 \mathrm{~b} \pm 512.75$ & $4849.11 \mathrm{~b} \pm 497.11$ & $4039.11 \mathrm{~b} \pm 497.11$ & $4194.32 \pm 433.77$ & & & & & & \\
\hline & 45 & $4749.42 \mathrm{ab} \pm 487.10$ & $6095.64 \mathrm{a} \pm 487.10$ & $4232.40 \mathrm{~b} \pm 471.60$ & $5025.82 \pm 415.14$ & & & & & & \\
\hline & Overall Average $(\mathrm{P})$ & $4031.66 \pm 246.18$ & $5113.05 \pm 246.18$ & $4380.99 \pm 242.26$ & & & & & & & \\
\hline
\end{tabular}


Table 6. Cont.

\begin{tabular}{|c|c|c|c|c|c|c|c|c|c|c|c|}
\hline \multirow{3}{*}{ Characteristic } & \multirow{3}{*}{$\begin{array}{c}\text { Levels Buffel Grass } \\
\text { Hay \% }\end{array}$} & \multicolumn{3}{|c|}{ Period (Days) } & \multirow{3}{*}{$\begin{array}{l}\text { Overall Average } \\
\text { (BH) }\end{array}$} & \multicolumn{3}{|c|}{$\mathrm{F}^{1}$ Test $p$-Value } & \multirow{2}{*}{\multicolumn{3}{|c|}{$\begin{array}{c}p \text {-Value }{ }^{2} \\
\% \text { BH }\end{array}$}} \\
\hline & & \multirow[b]{2}{*}{$1^{\circ}$} & \multirow{2}{*}{$7^{\circ}$} & \multirow{2}{*}{$21^{\circ}$} & & \multirow{2}{*}{ BH } & \multirow[b]{2}{*}{$\mathbf{P}$} & \multirow{2}{*}{ Interaction $(\mathrm{BH} \times \mathrm{P})$} & & & \\
\hline & & & & & & & & & L & $\mathrm{Q}$ & C \\
\hline \multirow[t]{5}{*}{ Eosinophiles, $\mu \mathrm{L}$} & 7.5 & $118.60 \mathrm{~b} \pm 26.66$ & $182.90 \mathrm{~b} \pm 24.44$ & $155.63 b \pm 26.66$ & $152.38 \pm 18.59$ & 0.0393 & 0.0001 & 0.0066 & 0.4268 & 0.0156 & 0.5424 \\
\hline & 15 & $97.22 b \pm 26.82$ & $173.96 \mathrm{~b} \pm 28.11$ & $205.79 b \pm 28.26$ & $158.99 \pm 19.61$ & & & & 0.3693 & 0.6334 & 0.0492 \\
\hline & 30 & $158.67 \mathrm{~b} \pm 26.82$ & $150.44 b \pm 26.82$ & $296.22 \mathrm{a} \pm 26.82$ & $201.78 \pm 19.19$ & & & & 0.0880 & 0.0028 & 0.2620 \\
\hline & 45 & $190.21 b \pm 26.66$ & $231.80 \mathrm{~b} \pm 25.44$ & $234.25 b \pm 26.66$ & $218.75 \pm 18.59$ & & & & & & \\
\hline & Overall Average (P) & $141.17 \pm 13.37$ & $184.78 \pm 13.23$ & $222.97 \pm 13.55$ & & & & & & & \\
\hline \multirow[t]{4}{*}{ Lymphocytes, $\mu \mathrm{L}$} & 7.5 & $2289.50 \pm 274.83$ & $2052.74 \pm 287.94$ & $2362.10 \pm 287.94$ & $2234.78 \pm 202.09$ & 0.0343 & 0.0124 & 0.0779 & 0.2054 & 0.0507 & 0.0771 \\
\hline & 30 & $2597.46 \pm 305.94$ & $1666.34 \pm 305.94$ & $2468.78 \pm 289.70$ & $2244.19 \pm 214.99$ & & & & & & \\
\hline & 45 & $3310.00 \pm 274.83$ & $2344.81 \pm 287.93$ & $2931.50 \pm 274.83$ & $2862.10 \pm 200.15$ & & & & & & \\
\hline & Overall Average $(\mathrm{P})$ & $2463.05 \mathrm{a} \pm 143.31$ & $2038.69 b \pm 146.49$ & $2540.37 \mathrm{a} \pm 142.81$ & & & & & & & \\
\hline \multirow[t]{5}{*}{ Monocytes, $\mu \mathrm{L}$} & 7.5 & $217.85 \mathrm{~b} \pm 49.38$ & $392.30 \mathrm{ab} \pm 47.26$ & $554.40 \mathrm{a} \pm 47.26$ & $388.18 \pm 35.64$ & 0.4195 & $<0.0001$ & 0.0024 & 0.1459 & 0.7624 & 0.4403 \\
\hline & 15 & $183.33 \mathrm{~b} \pm 49.82$ & $423.00 \mathrm{a} \pm 49.82$ & $379.28 \mathrm{ab} \pm 52.32$ & $32,854 \pm 37.61$ & & & & & & \\
\hline & 30 & $308.44 \mathrm{~b} \pm 49.82$ & $322.00 \mathrm{~b} \pm 49.82$ & $384.78 \mathrm{~b} \pm 49.82$ & $338.41 \pm 37.23$ & & & & & & \\
\hline & 45 & $318.90 \mathrm{~b} \pm 47.26$ & $484.10 \mathrm{~b} \pm 47.26$ & $398.50 \mathrm{~b} \pm 49.38$ & $400.50 \pm 35.64$ & & & & & & \\
\hline & Overall Average (P) & $257.13 \pm 24.54$ & $405.35 \pm 24.28$ & $429.24 \pm 24.86$ & & & & & & & \\
\hline \multirow{4}{*}{ Platelets, $\mu \mathrm{L}$} & 7.5 & $752,900 \pm 71,317$ & $699,300 \pm 71,317$ & $790,700 \pm 71,317$ & $747,633 \pm 60,078$ & 0.8455 & 0.2644 & 0.1051 & 0.7651 & 0.8834 & 0.4105 \\
\hline & 15 & $706,667 \pm 75,174$ & $843,111 \pm 75,174$ & $836,444 \pm 75,174$ & $795,407 \pm 63,328$ & & & & & & \\
\hline & 45 & $857,100 \pm 71,317$ & $906,800 \pm 71,317$ & $768,700 \pm 71,317$ & $810,867 \pm 60,078$ & & & & & & \\
\hline & Overall Average $(\mathrm{P})$ & $760,722 \pm 36,636$ & $758,422 \pm 36,636$ & $809,048 \pm 36,991$ & & & & & & & \\
\hline \multirow{5}{*}{$\begin{array}{l}\text { Total plasma } \\
\text { Protein., g/dL }\end{array}$} & 7.5 & $7.23 b \pm 0.10$ & $7.44 b \pm 0.09$ & $7.08 b \pm 0.09$ & $7.25 \pm 0.06$ & 0.5801 & $<0.0001$ & 0.0142 & 0.3311 & 0.3211 & 0.8704 \\
\hline & 15 & $7.03 \mathrm{~b} \pm 0.10$ & $7.52 \mathrm{a} \pm 0.10$ & $6.98 \mathrm{~b} \pm 0.10$ & $7.18 \pm 0.06$ & & & & & & \\
\hline & 30 & $7.00 \mathrm{~b} \pm 0.10$ & $7.30 b \pm 0.10$ & $7.46 b \pm 0.10$ & $7.25 \pm 0.06$ & & & & & & \\
\hline & 45 & $7.19 b \pm 0.09$ & $7.48 \mathrm{~b} \pm 0.10$ & $7.21 \mathrm{~b} \pm 0.09$ & $7.29 \pm 0.06$ & & & & & & \\
\hline & Overall Average (P) & $7.11 \pm 0.05$ & $7.43 \pm 0.05$ & $7.18 \pm 0.05$ & & & & & & & \\
\hline
\end{tabular}

${ }^{1} \mathrm{BH}=$ buffel grass hay; $\mathrm{P}=$ collection periods $;{ }^{2} \mathrm{~L}=$ Linear, $\mathrm{Q}=$ quadratic and $\mathrm{C}=$ cubic; ${ }^{3} \mathrm{CHCM}=$ corpuscular hemoglobin concentration mean; the means followed by different letters on the same line differ from each other by the Tukey test at $5 \%$ significance. 


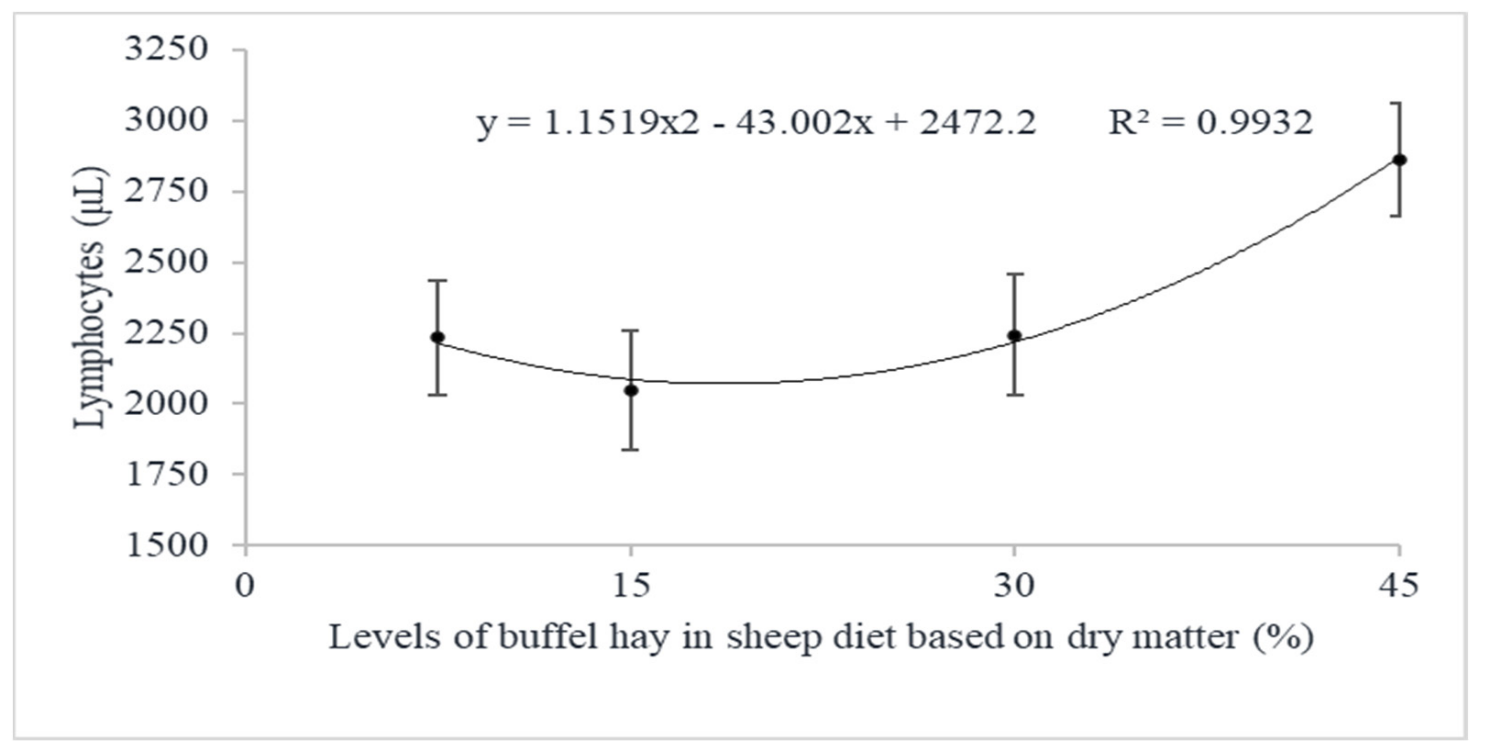

Figure 3. Effect of levels of buffel grass hay on lymphocytes.

There was an interaction $(p<0.0001)$ for monocytes (Table 6). On the 1st day of collection, animals consuming $7.5 \%$ buffel grass hay had lower monocyte values $217.8 \mu \mathrm{L}$ ) when compared to the 21 st day $(554.40 \mu \mathrm{L})$. In relation to the animals consuming $15 \%$ buffel grass hay, on the 7th day, the animals had higher values than on the 1st day. Animals fed $30 \%$ and $45 \%$ buffel grass hay showed no significant difference in monocytes between the collection periods.

Values of total plasma proteins showed interaction of buffel grass hay levels with collection periods. The highest concentration was found in animals consuming $15 \%$ buffel grass hay, on the 7 th day of collection $(7.52 \mathrm{~g} / \mathrm{dL})$.

\section{Discussion}

It is possible to infer that the growth of both Enterobacteriaceae and E. coli as reduced with the lowest proportions of cactus in the diets. At the level of $7.5 \%$ of buffel grass hay, there was a greater proliferation of these microorganisms, possibly due to the high moisture content in the diet. The moisture content is a factor that improves microbial growth, as it must be considered when the food is chopped and offered to the animals, since it can be exposed to the air for several hours, providing an ideal environment for development. of pathogenic microorganisms such as Enterobacteriaceae, including E. coli. Cactus pear is a food with high moisture content and its composition is rich in substrates for microbial fermentation, such as soluble carbohydrates. When cut into smaller structures, there is a greater surface area of the forage cactus available for access to nutrients by microorganisms, allowing for greater growth and fermentation [4].

This may have occurred due to the increase in the $\mathrm{pH}$ of the diet, as well as the greater exposure of the material to oxygen, when reducing the amount of cactus in the diet provided. However, the increase in the proportion of buffel grass hay, which has a more alkaline $\mathrm{pH}$ [14], combined with cactus pear mucilage that has as a buffer effect [15], in combination, may have created a suitable environment for the growth of these microorganisms. In addition, water in food can form a physical barrier for oxygen to enter material exposed to air, so the drier the food, the more easily air can penetrate it.

The interaction of high moisture content of the diet with $7.5 \%$ cactus pear, particles smaller than $2 \mathrm{~cm}^{2}$, and time of exposure to air in the diet, proved to be the combination that provides the highest counts of Enterobacteriaceae and E. coli in leftovers, which can lead to deterioration of the material as well as ingestion of foods with a high concentration of agents with the potential to harm the animal health. 
E. coli is the most common species in the intestines, and when found in water and food, it indicates fecal contamination, which can be pathogenic and cause diseases [16]. Very high counts may indicate the ingestion of contaminated food that culminates in the infection of the animal organism, causing diarrhea, intense fever and dehydration due to watery feces [4]. Probably, the processing of cactus before feeding the animal and stored in an environment with poor hygiene stimulates the growth of enterobacteria, reflecting in a diet with a higher bacterial count, therefore, high amounts of these bacteria can be excreted in the feces. Enterobacteriaceae are commonly found in the most diverse environments and in animals feces, thus poor hygiene environment could result in contamination of the rich cactus diets when feeding the animals, resulting in infections and diarrhea.

The lower count of these microorganisms in the leftovers on the 21st day in diets containing 7.5 and $45 \%$ buffel grass hay compared to the 1st day of the experimental period is probably due to the adaptation of the animals over the days to this high concentration of microorganisms.

The presence of Enterobacteriaceae and E. coli was expected since these microbial groups are present in the animal organism [16]. The microbiological counts of Enterobacteriaceae on the first experimental day are similar to the values reported by [4], who observed a count of $8.48 \mathrm{CFU} / \mathrm{g}$ in the diet with crushed cactus pear eight hours before feeding. In a biochemical profile test, the presence of E. coli in the feces of animals was confirmed, reinforcing that these microorganisms inhabit the gastrointestinal tract of sheep.

The highest count of Enterobacteriaceae and E. coli in feces of the animals on the first day of collection was possibly because the animals were still adapting to the levels of cactus pear in the diets, and it may be a consequence of the possible ingestion of a food with a higher bacterial load, given the higher count of these microorganisms in food leftovers, also on the first day of collection. However, throughout the experimental period, the animals become adapted to their diets, promoting a balance between the microorganisms present in the gastrointestinal tract of sheep, as the counts of Enterobacteriaceae and E. coli in feces were lower on the 21st day (Table 3).

Changes in the fecal score of sheep are related to the amount of cactus pear used in this study. The higher probability of fecal score two in animals fed $7.5 \%$ and $15 \%$ buffel grass hay is likely due to the lower DM content of these diets (Table 3). The animals had higher counts of Enterobacteriaceae and E. coli only on the first day of collection for these levels (Table 4) which suggest that that it was an effect of moisture on the microbial counts.

When cactus pear is offered in too high amounts in the ruminant diet and without the provision of an extra source of forage, changes in the characteristics of animal feces are observed, generally less solid than normal, due to the increased passage rate caused by the high amount of water available and low fiber content in the diet based on cactus pear [17].

Therefore, the opposite should also be taken into account, since the higher levels of fiber in the diet for ruminants can reduce the moisture content and regulate the passage rate through the gastrointestinal tract, also affecting the growth of Enterobacteriaceae and E. coli in the feed (Table 4), which interferes with the microbiota of the gastrointestinal tract and, consequently, with the occurrence of diarrhea in the animals (Table 4). As a consequence, the level of $45 \%$ buffel grass hay presented a fecal score equal to zero, which is considered the normal value for sheep.

There is a quadratic effect of the levels of buffel grass hay on the dry matter intake of the animals, in which the maximum intake of sheep is estimated at the level of $25.3 \%$ buffel grass hay (Table 4). The reduction in intake within the range of tested levels $(7.5$ and $45 \%$ FB) may be an adaptation of the animal to food with a high microbial load. Contaminated feed tends to reduce the intake in ruminants as this can cause negative effects on ruminal fermentation affecting the performance and health of animals [18].

A reduction in the dry matter intake of animals receiving diets with the highest counts of Enterobacteriaceae and E. coli was also observed [4]. Therefore, it can be assumed that the animals tended to consume a smaller amount of food due to its greater contamination, as a defense mechanism of the animal itself. 
When ruminants are fed low-fiber diets, their ruminal $\mathrm{pH}$ drops, their microbial ecology changes, and they become more prone to metabolic disturbs [16]. Evaluating the effect of dietary fiber level in relation to dry matter (DM) intake of feedlot sheep, [19] observed that DM intake increased linearly as dietary fiber levels increased from $8.67 \%$ to a maximum of $34.69 \%$. In the present study, dietary fiber levels were also increased according to the levels of buffel grass hay (Table 2) with DMI maximization with $25.3 \%$ buffel grass hay, above that, there was a gradual reduction in the DMI with the inclusion of this forage (Table 4). Considering that the $15 \%$ buffel grass hay diet contained $36.34 \%$ NDF and the $30 \%$ buffel grass hay diet contained $43.92 \%$ NDF (Table 3 ), the estimated dietary NDF value that would maximize the DMI was close to the cited authors. In addition to the high dietary $\mathrm{pH}$, which may have negatively influenced the microbiological quality of the diet, as discussed above, excess fiber can also depress the animal's DMI due to the filling effect [19].

There was an effect of interaction $(p<0.0001)$ on the belly temperature of the animals. However, this effect does not allow the inference of any pathological change in the animals, since, of the physiological parameters analyzed, rectal temperature and respiratory rate are the parameters that could indicate some type of anomaly in thermal comfort or in the health of the animals [20]. Nevertheless, the mean values of these parameters are in accordance with the reference values used by [21] for Dorper sheep that have been naturalized or crossed with native sheep, under tropical conditions, which are $38.3-39.9^{\circ} \mathrm{C}$ and 20-34 moves per minute, respectively. These results reinforce that the animals get adapted to a high load of potentially pathogenic microorganisms.

The way of managing diets can positively influence, favoring the animal adaptation to diets with microbiological risk, such as cactus pear. In the present study, cactus pear was crushed and immediately offered to the animals, and the leftovers were removed twice a day, with cleaning of the troughs before supplying a new meal. Studies prove that in diets with high levels of cactus pear, the provision of cactus pear to the animals, immediately after grinding, contributes to a significant drop in Enterobacteriaceae counts in sheep feces, as reported by [4]. Thus, the way of managing and using cactus pear in diets with high levels of this plant in its composition can interfere with the growth of microorganisms with pathogenic potential, which may be correlated with cases of nutritional disorders or reduced performance of sheep confined.

In the present study, an effect of interaction $(p<0.0001)$ was detected for the hemoglobin data, which were lower on the first day and higher in animals fed $45 \%$ buffel grass hay. Moreover, hematocrit values showed significant differences between collection periods, which may reinforce some anomaly in animal health (possible anemia) during the first days of the experimental period and a possible adaptation by these animals over the days. Thus, the results of blood parameters allowed inferring that the animals were able to adapt to the diets even with the high levels of cactus pear in its composition.

The mean values of erythrocytes, hemoglobin and hematocrit are close to those reported by [4,22]. Reference [4] concluded that animals can adapt to diets with high levels of cactus pear depending on the way of feed management. This study reinforces our findings, as it was carried out under similar conditions and with animals with the same genotype and phenotype patterns.

In the present study, animals fed $7.5 \%$ buffel grass hay had lower hemoglobin concentration values on the first day of collection, which would be explained by the fact that the animals are still adapting to their diets (Table 6). However, it is noteworthy that despite the lower means presented by the level of $7.5 \%$ buffel grass hay on the 1st day of collection, these values were within the reference range suggested in the complete blood count exam $(30-36 \mathrm{~g} / \mathrm{dL})$ and remained both in the second $(33.07 \mathrm{~g} / \mathrm{dL})$ and in the third collection $(32.90 \mathrm{~g} / \mathrm{dL})$.

Values of total leukocytes are responsible for indicating a possible infection in the animal organism, whether caused by viruses or bacteria, in suspected blood diseases, parasitic infections or allergic processes [23]. In the present study, values of total leukocytes 
at $15 \%$ buffel grass hay were lower on the first day of collection compared to the 7 th and 21st days, which may indicate an immune response of the animal to a possible infection caused by ingestion of foods with higher counts of Enterobacteriaceae and E. coli in the first days of the experimental period (Table 3). The highest counts of Enterobacteriaceae and E. coli in the animals' feces on the first day of collection coincide with the period of blood collection, in which the animals had the lowest total leukocyte counts, so it is possible to state that the microorganisms affected the health of the animals. Values of total leukocytes below those indicated may represent a condition of leukopenia, where severe cases suggest infections [23]. However, the total leukocyte counts on the 1st day of collection was $5277.78 \mu \mathrm{L}$, being within the reference range indicated by the complete blood count test, which is $4000-12,000 \mu \mathrm{L}$, indicating that despite the drop, the animals did not progress to more severe conditions and over the days, they managed to recover, through the immune system, because in the 2 nd collection period ( 7 th day) the concentration of total leukocytes increased (Table 6).

The increase in leukocytes indicates that there was a possible inflammatory or infectious process occurring in the organism. The reduction in the counts of Enterobacteriaceae and E. coli on the 21st day of the experimental period also demonstrates that the animals were able to recover from a possible infection over the experimental days, without major complications. Values of total leukocytes on the 21 st day, in animals fed $15 \%$ buffel grass hay, were similar to those found for healthy male Dorper sheep [24] which was $7576.0 \mu \mathrm{L}$, reinforcing that there was recovery of the animals over the days.

Values of segmented at the $15 \%$ inclusion level of buffel grass hay, on the first day of collection, may be related to the values of total leukocytes indicating the presence of an infection caused by bacteria. On the 7th day, the highest values indicate the immune response of the organisms and on the 21st day, the values reduced to a value that is in accordance with the reference literature $[6,24]$.

Some blood parameters of the animals were affected by the levels of buffel grass hay in the diet with inclusion of cactus pear. Most of them may be related to the highest total leukocyte count, since the lowest count was found at the level of $15 \%$ buffel grass hay inclusion on the 1st day of collection, and the highest on the 7th day of collection, with also the lowest (1st day) and highest (7th day) values for segmented, eosinophils, monocytes and plasma proteins. This indicates recovery by the animal organism from a possible bacterial infection caused by lower levels of buffel grass hay in the diet and higher concentrations of cactus pear.

Despite the pasty consistency presented by the feces of animals receiving $7.5 \%$ and $15 \%$ buffel grass hay, no cases of severe digestive disorders, such as totally liquid feces or even with the presence of blood were observed. Probably, defenses of the animal organism managed to prevent the appearance of diseases even at certain levels of food contamination. Thus, it can be stated that sheep become adapted to diets with high content of cactus pear and low fiber content from buffel grass hay, even those with higher counts of Enterobacteriaceae and E. coli.

Thus, high levels of cactus pear in the sheep diet alter the microbiological, blood and fecal parameters of confined sheep in the first periods of diet allowance, however, the animals manage to adapt to the diets without major complications.

The research results demonstrate that the cause of nutritional disorders in ruminants consuming diets with a high proportion of cactus pear is not exclusively due to the low fiber content of physically effective diets. The high concentration of non-fiber carbohydrates in fresh cactus pear, and the inadequate feeding management of this forage, can predispose the animals to contamination by pathogenic microorganisms that will negatively interfere with the animal health, causing, among other problems, diarrhea. As forages have a low content of NFC, in the form of hay, they contain low moisture, reduce the proliferation of microorganisms in diets with cactus pear, by decreasing the favorable environmental characteristics for the growth of these microorganisms. 
Nevertheless, it was also observed that sheep were able to adapt to diets with low levels of buffel grass hay. Thus, producers, especially in semiarid regions, can use cactus pear as a basis for the diet of confined sheep, provided it is correctly managed, so that the multiplication and ingestion of undesirable and possibly pathogenic microorganisms is avoided, for favoring secondary fermentations in the feeding trough of the animals.

Although physically effective fiber levels help to reduce nutritional disorders in sheep fed diets with high levels of cactus pear, the inadequate management of this food can also cause nutritional disorders. However, studies on the subject are still scarce, suggesting the need for more research to obtain more precise results.

\section{Conclusions}

Reducing the proportion of palm and adding more than $15 \%$ buffel grass on a dry matter basis provides less contamination of the diet and animal feces by enterobacteria, such as E. coli, without any negative change in blood parameters and reducing the occurrence of diarrhea in confined sheep.

Author Contributions: Conceptualization, D.d.S.V., J.S.d.O. and E.M.S.; methodology, E.M.S., B.R.C.d.S., D.F.O.C. and G.d.C.S., software, L.F.B.P., validation, B.R.C.d.S., D.F.O.C., M.A.C.S. and P.d.C.T.J., formal analysis, L.F.B.P., M.A.C.S. and N.B.V., investigation, D.d.S.V., J.S.d.O., E.M.S., D.F.O.C., G.d.C.S., P.d.C.T.J. and P.G.B.G., resources, N.B.V., P.d.C.T.J. and P.G.B.G. data curation, G.M.L. and R.L.S., writing - original draft preparation, D.d.S.V., J.S.d.O., E.M.S. and B.R.C.d.S., writing-review and editing, J.S.d.O., A.d.M.Z. and F.N.d.S.S., visualization, A.d.M.Z. and F.N.d.S.S., supervision, J.S.d.O. and E.M.S. project administration, J.S.d.O. and E.M.S., funding acquisition, J.S.d.O. All authors have read and agreed to the published version of the manuscript.

Funding: The research was supported by Foundation for Research Support of the State of Paraíba Pronex edital (finace code 06/2018), the National Council for Scientific and Technological Development (CNPq, Brazil). The Coordination for the Improvement of Higher Education Personnel (CAPES-Brazil, finance code 001) and Foundation for Research Scientific and Technological Development of Maranhão.

Institutional Review Board Statement: The research reported in our study was conducted in accordance with the bioethical rules and guidelines applicable to studies involving animals set forth by the Animal Ethics Committee (or the Ethics Committee on the use of animals in research) in Brazil, which is regulated by the Ethics Committee. This trial was carried out at the Federal University of Paraiba (UFPB) following the endorsements of the Committee on the Ethics of Animal Experiments (Protocol Number 5391070619) of UFPB.

Conflicts of Interest: The authors declare no conflict of interest.

\section{References}

1. Souza, B.B. Leite de Cabra: Raças Utilizadas e Sistemas de Alimentação Utilizados no Cariri Paraibano. 2015. Available online: https: / / www.milkpoint.com.br/artigos / producao/leite-de-cabra-racas-utilizadas-e-sistemas-de-alimentacao-utilizadosno-cariri-paraibano-70309n.a\%E2\%80\%A6 (accessed on 7 October 2019).

2. Pinho, R.M.A.; Santos, E.M.; Oliveira, J.S.; Carvalho, G.G.P.; Silva, T.C.; Macedo, A.J.S.; Correa, Y.R.; Zanine, A.M. Does the level of forage neutral detergent fiber affect the ruminal fermentation, digestibility and feeding behavior of goats fed cactus pear? Anim. Sci. J. 2018, 89, 1424-1431. [CrossRef] [PubMed]

3. Santos, A.O.A.; Batista, A.M.; Mustafa, A.; Amorim, G.L.; Guim, A.; Moraes, A.C.; Lucena, R.B.; Andrade, R. Effects of Bermudagrass hay and soybean hulls inclusion on performance of sheep fed cactus-based diets. Trop. Anim. Health Prod. 2010, 42, 487-494. [CrossRef] [PubMed]

4. Paulino, R.S.; Oliveira, J.S.; Santos, E.M.; Pereira, G.A.; Ramos, J.P.F.; Cesar Neto, J.M.; Cruz, G.F.L.; Leite, G.M.; Satake, F.; Silva, A.L.; et al. Spineless cactus use management on microbiological quality, performance, and nutritional disorders in sheep. Trop. Anim. Health Prod. 2021, 53, 53-168. [CrossRef] [PubMed]

5. Pinho, R.M.A.; Santos, E.M.; Oliveira, J.S.; Bezerra, H.F.; Carvalho, G.G.P.; Campos, F.S.; Pereira, G.A.; Correia, R.M. Avaliação de fenos de capim-buffel colhido em diferentes alturas de corte. Rev. Bras. Saúde Prod. Anim. 2013, 14, 437-447. [CrossRef]

6. Edvan, R.L.; Santos, E.M.; Da Silva, D.S.; De Andrade, A.P.; Costa, R.G.; Vasconcelos, W.A. Características de produção do capim-buffelsubmetido a intensidades e frequências de corte. Arch. Zootec. 2011, 60, 1281-1289. [CrossRef]

7. National Research Council (NRC). Nutrient Requirements of Small Ruminants: Sheep, Goats, Cervids, and New World Camelids; The National Academies Press: Washington, DC, USA, 2007. 
8. Association of Official Analytical Chemists. Official Methods of Analysis, 19th ed.; AOAC: Gaithersburg, MD, USA, 2012; p. 2610

9. Van Soest, P.J. Nutricional Ecology of the Ruminant, 2nd ed.; Cornell University Press: Ithaca, NY, USA, 1994; 476p.

10. Sniffen, C.J.; O'Connor, J.D.; Van Soest, J.P.; Fox, D.G.; Russell, J.B. A net carbohydrate and protein system for evaluating cattle diets: II. Carbohydrate and protein availability. J. Anim. Sci. 1992, 70, 3562-3577. [CrossRef] [PubMed]

11. Collier, H.B. Standardizations of blood haemoglobin determinations. Can. Med. Assoc. J. 1994, 50, 550-552.

12. Rosenfeld, G. Método rápido de coloração de esfregaços de sangue. Noções práticas sobre corantes pancrônicos e estudos de diversos fatores. Mem. Inst. Butantà 1947, 20, 315-328.

13. Rosalinski-moraes, F.; Fernandes, F.G.; Munaretto, A.; Oliveira, S.; Wilmsen, M.O.; Pereira, M.W.; Meirelles, A.C.F. Método FAMACHA@, escore corporal e de diarreia como indicadores de tratamento anti- helmíntico seletivo de ovelhas em reprodução. Biosci. J. 2012, 28, 1-12.

14. Bezerra, H.F.C.; Santos, E.M.; Oliveira, J.S.; Pinho, R.M.A.; Perazzo, A.F.; Silva, A.P.G.; Ramos, J.P.F.; Pereira, G.A. Fenos de capim-buffel amonizados com ureia. Rev. Bras. Saúde Prod. Anim. 2014, 3, 561-569. [CrossRef]

15. Macêdo, A.J.S.; Santos, E.M.; Oliveira, J.S.; Perazzo, A.F. Microbiologia de silagens: Revisão de Literatura. REDVET. Rev. Electrón. Vet. 2017, 18, 1-11.

16. Wanapat, M.; Cherdthong, A. Use of Real-Time PCR Technique in Studying Rumen Cellulolytic Bacteria Population as Affected by Level of Roughage in Swamp Buffalo. Curr. Microbiol. 2008, 58, 294-299. [CrossRef] [PubMed]

17. Pereira, G.A.; Santos, E.M.; Oliveira, J.S.; Araujo, G.G.L.; Paulino, R.S.; Perazzo, A.F.; Ramos, J.P.F.; Cesar Neto, J.M.; Cruz, G.F.L.; Leite, G.M. Intake, nutrient digestibility, nitrogen balance, and microbial protein synthesis in sheep fed spineless cactus silage. Small Rumin. Res. 2021, 194, 1-22. [CrossRef]

18. Vedovatto, M.G.; Bento, A.L.; Kiefer, C.; Souza, K.M.R.; Franco, G.F. Micotoxinas na dieta de bovinos de corte: Revisão. Arch . Zootec. 2020, 69, 234-244. [CrossRef]

19. Sousa, N.M.; Oliveira, J.S.; Santos, E.M.; Medeiros, A.N.; Brito, E.A. Levels of neutral detergent fiber in diets with forage palm for dairy goats. Arq. Bras. Med. Vet. Zootec. 2018, 70, 1595-1604. [CrossRef]

20. Halfen, J.; Rahal, N.M.; Barbosa, A.A.; Corrêa, M.N.; Del Pino, F.A.B.; Brauner, C.C.; Schmitt, E. Influência da restrição alimentar e do estresse térmico sobre parâmetros fisiológicos em ovinos. Arq. Bras. Med. Vet. Zootec. 2020, 72, 1911-1919. [CrossRef]

21. Seixas, L.; Peripolli, V.; Ficher, V.; Poli, C.H.E.C.; Melo, C.B.; Louvandini, H. Physiological and hematological parameters of sheep reared in the tropics and subtropics. Arq. Bras. Med. Vet. Zootec. 2021, 73, 622-630. [CrossRef]

22. Batista, M.C.S.; Castro, R.S.; Rego, E.W.; Carvalho, F.A.A.; Silva, S.M.S.; Carvalho, C.C.D.; Riet-Correa, F. Hemograma, proteinograma, ionograma e dosagens bioquímicas e enzimáticas de ovinos acometidos por conidiobolomicose no Nordeste do Brasil. Pesqui. Vet. Bras. 2009, 29, 17-24. [CrossRef]

23. Neves, R. O Que é o Leucograma? Entenda os Resultados do Exame! 2019. Available online: https://cuidadospelavida.com.br/saudee-tratamento/baixa-imunidade/leucograma (accessed on 5 July 2021).

24. Madureira, K.M.; Gomes, V.; Barcelos, B.; Zani, B.H.; Shecaira, C.L.; Benesi, F.J. Parâmetros hematológicos e bioquímicos de ovinos da raça Dorper. Semin. Ciênc. Agrár. 2013, 34, 811-816. [CrossRef] 